\title{
Mühendislik Öğrencilerinin E-Öğrenmeye Dair Beklenti, Hazır Bulunuşluk ve Memnuniyet Düzeyleri
}

\author{
Müge Adnan ${ }^{1}\left(\mathbb{D}\right.$ ve Burçak Boz-Yaman ${ }^{2}$
}

Makale geçmişi

Makale geliş tarihi: 22 Aralık 2016

Yay ina kabul tarihi: 13 Nisan 2017

Çevrimiçi yay ın tarihi: 5 Haziran 2017

\begin{abstract}
Öz: Bu çalışmanın amacı, Muğla Sıtkı Koçman Üniversitesi Mühendislik Fakültesi İnşaat ve Bilgisayar Mühendisliği Bölümü öğrencilerinin çevrimiçi teknolojiler kullanılarak harmanlanmış olarak tasarlanan Kalkülüs-2 dersi bağlamında e-öğrenmeye dair beklenti, hazır bulunuşluk ve memnuniyetlerini değerlendirmektir. Çalışmadan elde edilecek sonuçların dersin tasarımının iyileştirilmesinde kullanılması planlanmaktadır. İlişkisel tarama modeli kullanılan çalışmada, katılımcıların beklenti, hazır bulunuşluk ve memnuniyetleri cinsiyet, bölüm ve daha önceden e-öğrenme deneyimine sahip olup olmama durumlarına göre incelenmiştir. Araştırmada amaçlı örnekleme yöntemlerinden ölçüt örnekleme kullanılmış ve dönem başında yapılan beklenti ve hazır bulunuşluk çalışmasına 102 öğrenci, dönem sonunda yapılan memnuniyet çalısmasına ise 95 öğrenci katılmıştır. Elde edilen verilere göre Mühendislik Fakültesi öğrencilerinin e-öğrenmeden beklenti, hazır bulunuşluk ve memnuniyet düzeyleri ile devam ettikleri bölüm, cinsiyet ve daha önceden e-öğrenme deneyimine sahip olma durumlarına göre istatistiksel olarak anlamlı bir fark bulunamamıştır. $\mathrm{Bu}$ tür çalışmalardan elde edilen bulguların, Türkiye'de uzaktan eğitim yöntemiyle verilen ders ve programların niteliğinin artırılmasına katkı sağlayacağı düşünülmektedir.
\end{abstract}

Anahtar Kelimeler: Kalkülüs, e-öğrenme, hazır bulunuşluk, öğrenci memnuniyeti, uzaktan eğitim

DOI: $10.16949 /$ turkbilmat.280165

\begin{abstract}
The aim of this study is to examine expectations, and readiness and satisfaction levels of undergraduate students enrolled in Civil Engineering and Computer Engineering Departments of the Faculty of Engineering at Muğla Sttkı Koçman University, Turkey, for a blended Calculus course. Findings of the study will be used to draw implications for course improvement. Designed as a correlational survey, expectations, readiness, and satisfaction levels will be examined through quantitative measurement tools on the basis of gender, department, and prior exposure to online learning. A total of 102 students, selected based on criterion sampling, responded to expectancy and readiness survey administered at the beginning of the semester, whilst 95 responded to the satisfaction survey at the end of the semester. Findings indicate no significant statistical difference for expectation, readiness, and satisfaction levels of the engineering students as of gender, department and prior exposure to online learning. It is expected that findings from such studies will help to improve the design, development and implementation of online courses and programs in Turkey.
\end{abstract}

Keywords: Calculus, e-learning, readiness, learner satisfaction, online and distance learning

See Extended Abstract

\section{Giriş}

Bilgi ve iletişim teknolojilerinin öğrenme-öğretme ortamlarında başlattığı değişimle birlikte, sağladığı esneklik ve çeşitlilik avantajlarına bağlı olarak internet tabanlı uzaktan eğitim hızlı bir gelişim göstermiş, bu değişim yükseköğretim düzeyinde verilen ders ve

\footnotetext{
${ }^{1}$ Yrd. Doç. Dr., Muğla Sttkı Koçman Üniversitesi, Eğitim Fakültesi, Bilgisayar ve Öğretim Teknolojileri Eğitimi Bölümü, Muğla, Türkiye, mugea@mu.edu.tr

${ }^{2}$ Yrd. Doç. Dr., Muğla Sttkı Koçman Üniversitesi, Eğitim Fakültesi, Matematik ve Fen Bilimleri Eğitimi Bölümü, Muğla,

Türkiye,burcak@mu.edu.tr
} 
programların sunum şekillerini de değiştirerek üniversitelerde yeni örgütsel ve pedagojik modellerin işe koşulmasını gerektirmiştir (Tait, 2010). Alanyazında farklı isimlerle ifade edilen, ancak son dönemde elektronik öğrenme (e-öğrenme) veya açık ve uzaktan öğrenme (open and distance learning-ODL) kavramı altında değerlendirilen süreç, eğitmen ve öğrenenlerin zaman ve mekân sınırlaması olmadan bir araya geldiği, eğitmen, ögrenen ve ders içeriği arasındaki etkileşim için elektronik iletişim sistemlerinin kullanıldığı, disipline, eğitim düzeyine ve ders içeriğine göre farklı biçimlerde gerçekleştirilebilen ve bu nedenle de duruma özel ders tasarımı ve belirli idari düzenlemelerin yapılmasını gerektiren bir öğrenme sürecidir (Aydın, 2011; Moore \& Kearsley, 2012; Simonson, Smaldino, Albright \& Zvacek, 2012). Bates'e (2000) göre, yükseköğretim kurumları e-öğrenmeyi üç şekilde uygulayabilirler: (1) İnternetin geleneksel öğretimle bütünleştirildiği sunumlar ve elektronik olarak erişilebilir ders materyallerinin kullanıldığı teknoloji-tabanlı sınıf öğretimi; (2) dezavantajlı öğrencilerin eğitim erişimlerini artıran uzaktan öğrenme uygulamaları; (3) yüz yüze öğretim ile çevrimiçi öğrenme olanaklarının bir araya getirildiği harmanlanmış öğrenme uygulamaları (s. 22). Bates'in (2000) sınıflandırmasının üçüncü ayağını temel alan bu çalışmada, bir devlet üniversitesinde yüz yüze verilmekte olan bir dersin çevrimiçi teknolojilerle harmanlanması sonucu oluşan öğrenme deneyimine ilişkin olarak, dersi alan ögrencilerin beklenti, hazır bulunuşluk ve memnuniyet düzeylerinin değerlendirilmesi amaçlanmıştır.

Dünyada ilk olarak 19. yüzyılda mektupla eğitim olarak başlayan açık ve uzaktan öğrenme uygulamaları teknolojinin gelişmesiyle birlikte ilerlemiş ve 2000'li yıllara gelinirken bilgisayar ve internet teknolojilerinin gelişmesiyle evrilerek daha erişilebilir (ve daha popüler) bir hal almıştır (Moore \& Kearsley, 2012). Benzer şekilde, Türkiye'de 1996'da ODTÜ'nün iki sertifika programıla öncülük ettiği çevrimiçi öğrenme programları giderek yaygınlaşmış, 2000'li yılların başında sertifika ve lisansüstü düzeyde sunulan programlarla başlayan süreç son yıllarda birçok üniversitede çeşitli alanlarda önlisans, lisans, lisans tamamlama ve yüksek lisans programlarının açılmasıyla nicelik açısından ivme kazanmıştır. Bugün itibariyle, Türkiye'de 184 yükseköğretim kurumunun 68 'inde önlisans, lisans, lisans tamamlama ve yüksek lisans düzeylerinde toplam 505 açık ve uzaktan öğrenme programı olduğu saptanmıştır (Koçlar ve Doğan, 2015). Bunun yanı sıra çoğu üniversite, Bilgi Teknolojileri, Atatürk İlkeleri ve İnkılâp Tarihi, Türk Dili ve yabancı dil gibi ortak zorunlu dersler ile bazı bölüm derslerini uzaktan vermektedir. Ne yazık ki, bu dersler ve programlar tasarlanırken çoğu zaman geleneksel yüz yüze eğitim modelleri aynen aktarılmakta (Çelen, Çelik ve Seferoğlu, 2011), çevrimiçi dersler ve programlar bu modellerin kötü bir taklidinden öteye geçememektedir.

Gerek farklı nedenlerle geleneksel eğitime erişemedikleri için bilinçli olarak uzaktan eğitim programlarına kayıt olan öğrencilerin gerekse kayıt oldukları yüz yüze eğitim programlarındaki çevrimiçi yöntemlerle verilen derslere mecburen kaydolan öğrencilerin çevrimiçi öğrenmenin sağladığı avantajlardan faydalanabilmeleri için, belirli teknik ve öğretimsel becerilere sahip olmaları ve çevrimiçi öğrenmeye hazır bulunmaları gerekir. Daha önceki deneyimleri ve hazır bulunuşlukları doğrultusunda çevrimiçi öğrenme ortamlarından belli beklentileri olan öğrencilerin çevrimiçi öğrenmeye ne kadar hazır olduklarını belirlemek ve çevrimiçi öğrenme ortamlarından beklentilerini değerlendirmek, 
bu ortamların doğru ve etkin bir şekilde tasarlanması ve kullanılması açısından önem taşımaktadır (Hukle, 2009). Hazır bulunuşluk ve beklenti ile birlikte, öğrencilerin çevrimiçi öğrenme deneyimlerinden memnuniyet düzeyleri de, hem eğitmenler hem de öğretim tasarımcıları ve diğer paydaşlar açısından önemli olup, sunulan ders veya programın değerlendirilip gerekirse yeniden düzenlenerek öğrenme ortamının niteliğinin artırılmasına katkı sağlamaktadır.

\section{1. e-Öğrenme ve Haz rbulunuşluk}

Hazırbulunuşluk eğitim sürecindeki önkoşul bilgi ve becerilere sahip olma olarak tanımlanmaktadır (Senemoğlu, 2009). Çevrimiçi öğrenmeye hazır bulunuşluk kavramı ise Warner, Christie ve Choy (1998) tarafindan Avusturalya mesleki eğitim sistemi çerçevesinde kullanılmış ve üç açıdan tanımlanmıştır: (1) öğrencilerin yüz yüze eğitime karş1 tercih ettikleri eğitim şekli, (2) öğrencilerin elektronik iletişim (özellikle İnternet ve bilgisayar aracılı iletişim) araçlarını kullanma yeterlilikleri ve güvenleri ve (3) bağımsız öğrenmeye katılma becerisi.

Borotis ve Poulymenakou (2004) çevrimiçi öğrenmeye hazır bulunuşluğu "bazı çevrimiçi öğrenme deneyim ve eylemleri için zihinsel ve fiziksel olarak hazırlıklı olma" şeklinde tanımlamıştır. Shraim ve Khlaif (2010) e-hazır bulunuşluk olarak da adlandırılan bu durumu kullanabilirlik, bireysel yetkinlik, motivasyon ve engeller olmak üzere dört boyut altında ele almıştır. Bazı çalışmalarda e-hazır bulunuşluğa ilişkin olarak dikkate alınması gereken faktörler arasında kişisel özelliklere (Dada, 2006), bilgi ve iletişim teknolojileri (BIT) yeterliliğine ve teknolojiye erişime (Dada, 2006; Hanafizadeh, Hanafizadeh \& Khodabakhshi, 2009; Stephen, Mutula \& Brakel, 2006; Watkins, Leigh \& Triner, 2004), motivasyon, çevrimiçi ses-video kullanımı ve tartışmaya (Watkins ve ark., 2004) yer verilmektedir. Son dönemde Yurdugül ve Sirakaya (2013) tarafından Türkçe’ye uyarlanan Hung, Chou, Chen ve Own'un (2010) çevrimiçi öğrenmeye hazır bulunuşluk anketinde ise beş boyut bulunmaktadır: özgüdümlü öğrenme, motivasyon, öğrenen kontrolü, bilgisayar-internet özyeterliği ve çevrimiçi iletişim özyeterliğii. 2004 yılında Watkins ve arkadaşları tarafından geliştirilen ve Kalelioğlu ve Baturay (2014) tarafından Türkçe'ye uyarlanan e-öğrenme için Hazır Bulunuşluk Öz Değerlendirme ölçeği ise, bu kavramı altı boyutta ele almaktadır: başarının önemi, çevrimiçi ilişkiler, teknik beceriler, teknoloji erişimi, motivasyon ve çevrimiçi beceriler.

Kişisel özellikler, BİT yetkinliği, motivasyon ve teknolojiye erişim hemen hemen tüm çalışmalarda çevrimiçi öğrenmeye ilişkin hazır bulunuşluğu etkileyen faktörler arasında yer almaktadır. Alanyazın temelinde gerçekleştirdiği çalışmada, Gülbahar (2012a) çevrimiçi öğrenme için hazır bulunuşluğu etkileyen toplam beş faktör ortaya koymaktadır: Kişisel özellikler, teknolojiye erişim, teknik beceriler, motivasyon ve tutum, ve başarıyı etkileyen faktörler. Mevcut çalışmada da, hazırbulunuşluk kavramı Gülbahar'ın (2012a) çalışmasında ifade edilen bu faktörler etrafında ele alınmaktadır. 


\section{2. e-Öğrenme ve Memnuniyet}

Öğrencinin çevrimiçi öğrenme sürecinden memnuniyeti, çevrimiçi öğrenmenin tasarımını, sunumunu, işleyişini ve niteliğini şekillendiren en önemli faktörlerden biridir (Gülbahar, 2012b). Memnuniyet düzeyini etkileyen faktörlerin incelendiği çalışmalara bakıldığında, Beqiri, Chase ve Bishka'nın (2009) çevrimiçi teknolojileri kullanarak ögrenmeye karşı olumlu tutumu olan ve bu teknolojileri kullanma konusunda yetkin olan kişilerin memnuniyetlerinin daha fazla olduğu sonucuna ulaştı̆g 1 görülmüştür. Benzer bir çalışmada Pena ve Yeung (2010) da, BİT yetkinliğinin düzeyi azaldıkça memnuniyet düzeyinin de düştüğü sonucuna ulaşmışlardır. Bray, Aoki ve Dlugosh (2008) çevrimiçi öğrenme sürecinin güçlükleri ile başa çıkabilen, bilgisayarı rahatlıkla kullanabilen, eğitmenler ile rahat iletişim kurabilen ve bireysel öğrenme sürecini tercih eden öğrencilerin memnuniyet düzeylerinin daha yüksek olduğunu tespit etmişlerdir. Benzer şekilde Jung-Wan ve Mendlinger (2011) de kişisel yeterlik algısının ve e-öğrenme sistemlerinin kullanışlılığının memnuniyeti olumlu yönde etkilediğini tespit etmiştir.

Diğer çalışmalara bakıldığında, öğrenenlerin çevrimiçi öğrenme sürecinden memnun olma durumunu etkileyen faktörler arasında öğrencilerin çevrimiçi iletişim kurma ve başarı inancı (Palmer \& Holt, 2009), idari ve teknik personelin yeterliği ile öğrenenlerin teknoloji yetkinliği (Machado, 2007), yapılandırılmış ve etkileşimli ders ler (Lee \& Rha, 2009) ve kullanılan öğrenme yönetim sisteminin özellikleri (Palmer \& Holt, 2010), öğrenen-öğrenen ve öğrenen-eğitmen etkileşim yer almaktadır. Buna göre, öğrenenlerin teknik yeterliklerinin, öğretim sürecinin, eğitmenlerin teknik ve pedagojik yeterliklerinin, öğretim içeriğinin, çevrimiçi öğrenme yaklaşımına karşı tutumun, etkileşim düzeylerinin ve öğrenme yönetim sisteminin kullanışlılığının öğrenen memnuniyetini etkilediğinden bahsedilebilir (Ilgaz \& Gülbahar, 2015).

\subsection{Mühendislik Eğitiminde e-Öğrenme}

Mühendislik eğitiminde e-öğrenme, mühendislik bölümünün eğitim programında bulunan derslerin teknik ağırlıklı olması, derslerin işlenmesi esnasında daha çok çizim, grafik, animasyon, simülasyon gibi araçların kullanılması ve buna ek olarak laboratuvar ve uygulama oturumları içermesi nedeniyle çok sık tercih edilen bir yöntem değildir (Özkul, 2003). Ancak; genel mühendislik eğitiminin \%17'sini oluşturan Matematik ve Temel Bilimler derslerinden biri olan Kalkülüs dersi, birçok üniversitenin mühendislik fakültesi bölümlerinde uzaktan eğitim yoluyla da yapılmaktadır. Sadece mühendislik eğitiminde değil, Kalkülüs dersini veren tüm fakültelerde ve özellikle matematik bölümlerinde bu dersin uzaktan eğitim yöntemiyle verilmesi giderek artış göstermektedir. ABD Matematik Bilimleri Kurulu Konferansı'nda sunulan 2010 yılı araştırma sonuçlarına göre, dört y1llık öğretim veren Matematik bölümlerinin \%35'i derslerini uzaktan eğitim ile sunarken, bunlardan \%72'si de bölüm derslerini tamamen uzaktan olarak işlemektedir (Blair, Kirkman \& Maxwell, 2013). Hatta Kalkülüs dersini uzaktan eğitim ile veren üniversite sayısında 2000 yılından 2005 yılına kadar \%300'lük bir artış olduğu ortaya konmuştur (Kirkman, Lutzer, Maxwell \& Rodi, 2007'den akt., Trenholm, 2013, s. 25).

$\mathrm{Bu}$ oranda hızla artan matematik derslerinin uzaktan eğitim ile verilmesi sürecinde, öğrencilerin öğrenme deneyimlerini doğrudan etkileyecek bu tür kararlar öncesinde, 
öğrenen kitleyi oluşturan öğrencilerin farklı bir yöntemle almaya başlayacakları dersler için beklentilerinin değerlendirilmesi ve süreç sonunda memnuniyetlerinin ölçülerek gereken düzenleme ve iyileştirmelerin yapılması gerekmektedir.

Bu noktadan hareketle, bu çalışma, Mühendislik Fakültesi eğitim programında birinci yılda okutulan Kalkülüs-2 dersini alan öğrencilerin, çevrimiçi teknolojiler yardımıyla harmanlanmış olarak yeniden tasarlanan derse ilişkin beklentilerini, e-öğrenmeye hazırbulunuşluklarını ve e-öğrenme deneyimlerine dair memnuniyetlerini değerlendirmeyi amaçlamaktadır. Çalışmada, Mühendislik Fakültesi İnşaat ve Bilgisayar Mühendisliği öğrencileri çevrimiçi öğrenme öncesi ve sonrasında izlenmiş ve elde edilen bulgular cinsiyet, bölüm ve önceden e-öğrenme deneyimine sahip olma durumuna göre irdelenmiştir. Elde edilen bulguların, dersin tasarım, geliştirme ve uygulama sürecini iyileştirmesinde kullanılması planlanmaktadır. Bu bağlamda araştırmanın problemleri aşağıdaki gibidir:

1. Öğrencilerin e-öğrenme sürecine ilişkin hazır bulunuşluk, beklenti ve memnuniyet düzeyleri nedir?

2. Öğrencilerin e-öğrenme sürecine ilişkin hazır bulunuşluk, beklenti ve memnuniyet düzeyleri bölümlerine göre farklılaşmakta mıdır?

3. Öğrencilerin e-öğrenme sürecine ilişkin hazır bulunuşluk, beklenti ve memnuniyet düzeyleri cinsiyete göre farklılaşmakta mıdır?

4. Öğrencilerin e-öğrenme sürecine ilişkin hazır bulunuşluk, beklenti ve memnuniyet düzeyleri önceden çevrimiçi öğrenmeye maruz kalıp kalmama durumuna göre farklılaşmakta mıdır?

\section{Yöntem}

$\mathrm{Bu}$ araştırma, ilişkisel tarama modeline uygun olarak düzenlenmiştir. Karasar'a göre ilişkisel tarama modelleri "iki veya daha çok sayıdaki değişken arasında birlikte değişim varlığını ve/veya derecesini belirlemeyi amaçlayan araştırma modelleridir” (1991, s. 81).

\section{1. Öğrenme Ortamı}

Muğla Sıtkı Koçman Üniversitesi, Uzaktan Eğitim Merkezi aracılığıyla 2012 yılında başladığı uzaktan eğitim çalışmaları kapsamında ön lisans, lisans tamamlama ve yüksek lisans düzeyindeki programlarına ek olarak ortak zorunlu dersler ile bazı zorunlu ve seçmeli bölüm derslerini çevrimiçi teknolojileri kullanarak tamamen uzaktan veya harmanlanmış olarak vermektedir. Üniversitenin ortak zorunlu derslerinin çevrimiçi teknolojiler kullanarak verilmeye başlanmasıyla zorunlu matematik derslerinin çevrimiçi platforma taşınması konusunda çalışmaya başlayan yazarlar, ders öncesinde öğrencilerin hazır bulunuşluk ve beklentilerini, ders sonunda ise memnuniyet düzeylerini ölçerek dersin tasarım, işleyiş ve niteliğini artırmayı amaçlamışlardır. Bu çalışma, Mühendislik Fakültesinde 2013-2014 eğitim öğretim yılı bahar döneminde gerçekleştirilmiştir. 
Öğretim programında yer alan haftalık konulara göre harmanlanmış modelde yeniden tasarlanan dersin sekiz haftası sınıfta yüz yüze, altı haftası ise çevrimiçi teknolojiler kullanılarak uzaktan işlenmiştir. Tablo 1 'de verilen dönem ders planında da görüleceği gibi, dersin uzaktan işlenen haftaları belirlenirken, geleneksel yüz yüze sınıf ortamı içerisinde kullanılması mümkün veya pratik olmayan teknoloji araç ve uygulamalarından üst düzey fayda sağlanacak görsel ve etkileşimli materyallerin kullanılabileceği konuların yer aldığı haftalar olmasına dikkat edilmiştir.

Tablo 1. Dönem ders planı

\begin{tabular}{lll}
\hline & Konu & Yöntem \\
\hline Hafta 1 & Türev ve Türev Uygulamaları & Yüz yüze \\
Hafta 2 & $\begin{array}{l}\text { Anti-Türev. İntegral: Alan Hesaplamaları, Belirli } \\
\text { İntegral. }\end{array}$ & Yüz yüze \\
Hafta 3 & Belirli İntegral Özellikleri, Kalkülüsün Temel Teoremi & Yüz yüze \\
Hafta 4 & Belirsiz İntegral & Çevrimiçi \\
Hafta 5 & Belirsiz İntegral Uygulamaları: Hacim Hesaplamaları & Çevrimiçi \\
Hafta 6 & İntegral Alma Teknikleri & Yüz yüze \\
Hafta 7 & Has Olmayan İntegraller & Yüz yüze \\
Hafta 8 & Sonsuz Diziler ve Seriler & Çevrimiçi \\
Hafta 9 & Pozitif Terimli Seriler İçin Yakınsaklık Testi & Çevrimiçi \\
Hafta 10 & Alterne Seriler ve Mutlak Yakınsaklık & Yüz yüze \\
Hafta 11 & Kuvvet Serileri Taylor ve Maclaurin Serileri & Yüz yüze \\
Hafta 12 & Taylor Polinomları ve Taylor Formülü & Yüz yüze \\
Hafta 13 & Taylor Polinomları Uygulamaları & Çevrimiçi \\
Hafta 14 & Çok Katlı İntegraller & Çevrimiçi \\
\hline
\end{tabular}

Dersi yürüten öğretim üyesi tarafından çevrimiçi ortam için hazırlanan materyaller; ders notları, sunumlar, alıştırma kağıtları, çalışma kağıtları, animasyonlar, web bağlantıları ve etkinliklerden oluşmaktadır. Tüm ders materyalleri, üniversitenin ders yönetim sistemi (DYS) olarak kullandığı MOODLE (Modular Object-Oriented Dynamic Learning Environment) ortamına yüklenmiştir. Çevrimiçi dersler, hareketli kamera, akıllı tahta, vb. donanımlı üniversite stüdyolarında Adobe Connect video konferans programı kullanılarak yapılmıştır. Sanal sınıfta yapılan derslerin kayıtları, daha sonra DYS'ne eklenmiştir. Bu sayede, dersi kaçıran veya tekrar etmek isteyen öğrencilerin sanal sınıf kayıtlarına istedikleri zaman erişebilmeleri sağlanmıştır. Dersin DYS’ndeki sayfasına ve sanal sınıflardan alınan örnek akıllı tahta ekran görüntüsü Şekil 1'de verilmektedir. 


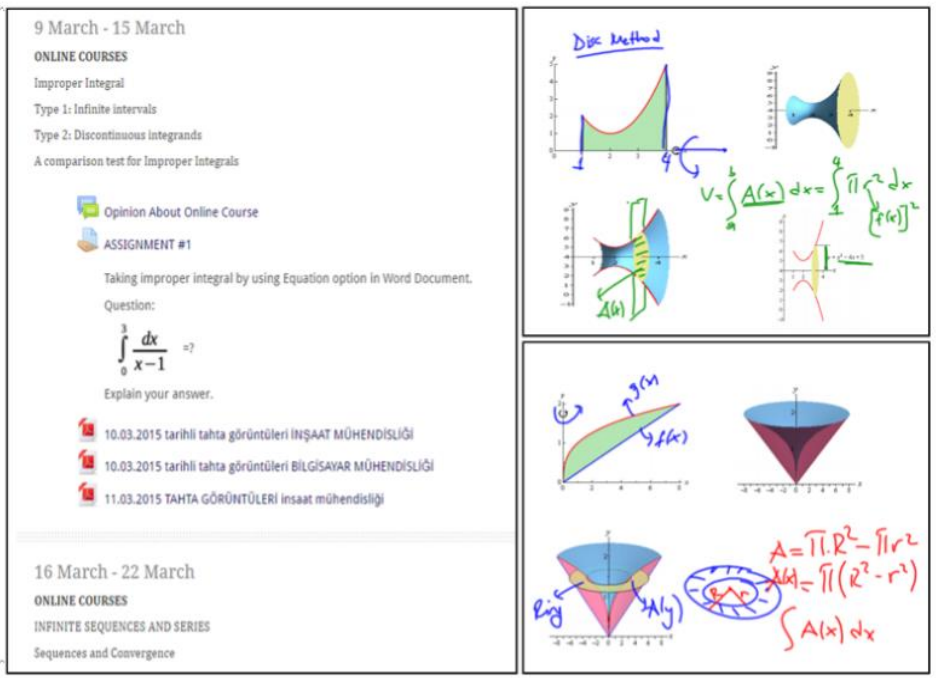

Şekil 1. Ders sayfası ve akıllı tahta ekran görüntüsü

\subsection{Katılımcılar}

$\mathrm{Bu}$ araştırmanın ulaşılabilir evreni, ilgili üniversitenin Mühendislik Fakültesi öğrencileridir. Bu evren içerisinden amaçlı örnekleme yöntemlerinden ölçüt örnekleme yöntemi kullanılarak belirlenen çalışmanın katılımcıları, Mühendislik Fakültesi Bilgisayar Mühendisliği ve İnşaat Mühendisliği bölümlerine kayıtlı olan ve zorunlu Kalkülüs-2 dersini alan birinci sınıf öğrencileridir. Tablo 2'de öğrencilerin bölüm ve cinsiyet gruplarına göre dağılımları, demografik bilgileri, çalışmada kullanılan hazır bulunuşluk ve beklenti ölçeği ile memnuniyet ölçeğine katılımları bağlamında verilmiştir. Öğrencilerin yaş ortalamas $120,85^{\prime}$ 'dir.

Tablo 2. Katılımcı bilgileri

\begin{tabular}{|c|c|c|c|c|}
\hline & \multicolumn{2}{|c|}{$\begin{array}{c}\text { Hazır Bulunuşluk ve } \\
\text { Beklenti }\end{array}$} & \multicolumn{2}{|c|}{ Memnuniyet } \\
\hline & $\mathrm{f}$ & $\%$ & $\mathrm{f}$ & $\%$ \\
\hline \multicolumn{5}{|l|}{ Bölüm } \\
\hline Bilgisayar Mühendis liği & 37 & 36 & 54 & 57 \\
\hline İnşaat Mühendis liği & 65 & 64 & 41 & 43 \\
\hline \multicolumn{5}{|l|}{ Cinsiyet } \\
\hline Kadın & 21 & 21 & 21 & 22 \\
\hline Erkek & 81 & 79 & 74 & 78 \\
\hline \multicolumn{5}{|l|}{ Uzaktan Eğitim Alma Durumu } \\
\hline Evet & 86 & 84 & $*$ & $*$ \\
\hline Hayır & 16 & 16 & & \\
\hline Toplam & 102 & 100 & 95 & 100 \\
\hline
\end{tabular}

* Uzaktan eğitim alma durumu verileri, çalışmanın başında hazırbulunuşluk ve beklenti ölçeğinde toplanmıştır. 


\subsection{Veri Topl ama Araçları}

Öğrencilerin e-öğrenme ortamlarındaki hazır bulunuşluklarını ve beklenti düzeylerini belirlemeye yönelik olarak Gülbahar (2012a) tarafından geliştirilen e-Öğrenme Sürecine İlişkin Hazır Bulunuşluk ve Beklenti Ölçeği kullanılmıştır. Maddeleri "1-Hemen hemen hiçbir zaman" ve "5-Hemen hemen her zaman" arasında değerlenen ölçek, beş faktör altında gruplanan 26 maddeden oluşmaktadır. Kişisel Özellikler(KÖ), Teknolojiye Erişim (TE) ve Motivasyon ve Tutum (MvT) faktörleri altında dörder, Teknik Beceriler (TB) faktörü altında sekiz ve Başarıyı Etkileyen Faktörler (BEF) altında altı madde bulunmaktadır. Gülbahar'ın (2012a) çalışmasında ölçeğin geçerlik ve güvenirlik çalışması yapılmış olup, Cronbach $\alpha$ değeri 0.93 olarak rapor edilmiştir. Bu çalışma kapsamında hesaplanan değer 0.90 'dır.

Öğrencilerin e-öğrenme sürecine ilişkin memnuniyetlerini belirleme yönelik olarak Çevrimiçi Matematik Derslerinde Öğrenci Memnuniyetinin Ölçülmesi başlıklı doktora çalışması kapsamında Davis (2014) tarafından geliştirilen Çevrimiçi Öğrenme Memnuniyet Ölçeği kullanılmıştır. Araştırmacılar tarafından Türkçe'ye uyarlanan ölçek, hem İngilizceyi hem de Türkçeyi iyi derecede bilen araştırmacı tarafından Türkçe'ye çevrilmiş ve dil eşdeğerliği için çeviri konusunda profesyonel olan uzmanlar tarafindan İngilizce'ye geri çevirisi yapılarak iki form arasındaki tutarlılık incelenmiştir. Üzerinde görüş birliğine varılan maddeler aynı şekliyle ölçeğe dahil edilmiş, görüş birliği olmayan maddeler ise görüşülerek ortak kabul edilen haliyle benimsenmiştir. Maddeleri " 1 Kesinlikle Katılmıorum" ve "5-Kesinlikle Katılıyorum" arasında değerlenen ölçek, altı faktör arasında gruplanan 18 maddeden oluşmaktadır. Orijinal ölçekte yer alan Geri Bildirimin Etkinliği ve Geri Bildirimin Zamanlaması faktörleri ödev ve uygulama oturumları yüz yüze yapıldığı için veri toplama aracından çıkarılmıştır. Tartışma ve Forum Kullanımı (TFK), Öğrenci-Eğitmen Diyaloğu (ÖED), Çevrimiçi Deneyim Algısı (ÇDA), Eğitmen Özellikleri (EÖ), Öğrenme Topluluğu Hissi (ÖTH) ve Bilgisayar Destekli İletişim (BDI) faktörlerinin her birinin altında üçer madde bulunmaktadır. Davis'in (2014) çalışmasında ölçeğin geçerlik ve güvenirlik çalışması yapılmış olup, Cronbach $\alpha$ değeri 0.98 olarak rapor edilmiştir. Bu çalışma kapsamında ise, Geri Bildirimin Etkinliği ve Geri Bildirimin Zamanlaması faktörleri ölçekten çıkarıldıktan sonra hesaplanan Cronbach $\alpha$ değeri 0.94'dür.

\subsection{Veri Analizi}

Öğrencilerin e-Öğrenme Sürecine İlişkin Hazır Bulunuşluk ve Beklenti Ölçeği ile Çevrimiçi Öğrenme Memnuniyet Ölçeğinden aldıkları puanlar, bir istatistiksel paket program kullanılarak analiz edilmiştir. Elde edilen veriler üzerinde aritmetik ortalama, standart sapma, mod, medyan ve frekans gibi betimleyici analizler ile t-testi ve ANOVA analizleri gerçekleştirilmiş, anlamlılık düzeyi 0.05 olarak kabul edilmiştir.

\section{Bulgular}

Çalışmanın bulguları, katılımcıların e-öğrenme esnasında hazır bulunuşluk ve beklentileri, süreç bittikten sonraki memnuniyetleri ve bu iki durumun karşılaştırmasını içeren üç başlık altında sunulmaktadır. 


\subsection{Hażr Bulunuşluk ve Beklenti Bulguları}

Mühendislik öğrencilerinin e-öğrenme sürecine ilişkin hazır bulunuşluk ve beklentilerini ölçmek üzere e-Öğrenme Sürecine İlişkin Hazır Bulunuşluk ve Beklenti Ölçeğinden toplanan verilerden elde edilen bulgular iki ayrı başlık altında incelenmiştir. Uygulanan ölçeğin "Hazır Bulunuşluk" boyutlarının (Kişisel Özellikler, Teknik Özellikler, Teknolojiye Erişim) ortalamalarına bakıldığında en yüksek ortalamaya Teknolojiye Erişim boyutunun sahip olduğu görülmektedir ( $\bar{x}=4,41 ; \mathrm{ss}=0,75)$.

Tablo 3. Teknolojiye erişim alt-boyutu maddelerinin ortalamaları

\begin{tabular}{llcc}
\hline No & Maddeler & Ort. & SS \\
\hline 6 & Internet bağlantısı bulunan bir bilgisayara erişimim var. & 4,40 & 1,184 \\
8 & Erişim sağladı̆ım bilgisayarda gerekli tüm yazilımlar rahatıkla & 4,33 & 1,021 \\
& & \\
& çalısabilir. & 4,24 & 1,133 \\
7 & Erş̧im sağladı̆̆m bilgisayar oldukça yeni bir teknolojiye sahiptir. & 4,21 & 1,244 \\
5 & e-Öğrenme sürecinde derslere evden katılabilirim. & & \\
\hline
\end{tabular}

Tablo 3'de de görüldügü gibi bulgular, katılımcıların derslere evlerinden veya herhangi bir yerden iyi donanımlı ve hızlı İnternet bağlantısına sahip bir bilgisayar kullanarak bağlanmayı tercih ettiklerini göstermektedir.

Ortalama puanı yüksek olan ikinci boyut ise Teknik Beceriler boyutudur ( $\bar{x}=4,28$; $\mathrm{ss}=0,93$ ). Buna göre, temel bilgisayar, İnternet bilgisine sahip olma ve bilgisayarı rahatlıkla kullanma durumu da katılımcıların hazır bulunuşluklarında önemli bir etmen olarak karşımıza çıkmaktadır.

Tablo 4. Teknik beceriler alt-boyutu maddelerinin ortalamaları

\begin{tabular}{llcc}
\hline No & Maddeler & Ort. & SS \\
\hline 15 & Sosyal paylaşım ortamlarını rahatlıkla kullanabilirim. & 4,65 &, 687 \\
16 & İnternet servislerini bilgiye erişim için rahatllkla kullanabilirim. & 4,58 &, 791 \\
14 & İnernet üzerindeki iletş̧im araçlarını rahatlkla kullanabilirim. & 4,55 &, 783 \\
11 & Bilgisayara ilişkin temel işlemler için gerekli becerilere sahibim. & 4,49 &, 934 \\
13 & İnternet kullanımına ilişkin temel becerilere sahibim. & 4,45 &, 911 \\
9 & e-Öğrenme yöntemi ile öğrenebilecek düzeyde bilgi ve iletişim & 4,31 & 1,093 \\
& teknolojilerini kullanmayı biliyorum. & & \\
10 & Bilgisayar ve İnternet kullanımı konusunda kendime güvenirim. & 4,29 &, 898 \\
12 & İçerik iletimi ve sunumu için ofis programlarını rahatllkla & 4,13 & 1,051 \\
& kullanabilirim. & & \\
\hline
\end{tabular}

Tablo 4'de görüldüğü gibi, bu boyut altındaki en yüksek puanları, sosyal paylaşım ortamlarını, internet servislerini ve internet üzerindeki iletişim araçlarını rahatlıkla kullanabilme ile ilgili maddeler almaktadır.

Bireylerin e-öğrenmeye ilişkin tercihlerini anlatan Kişisel Özellikler boyutu ( $\bar{x}=3,52$; ss $=0,87$ ) Tablo 5 'de görüldüğü gibi son sırada yer almaktadır. 
Tablo 5. Kişisel özellikler alt-boyutu maddelerinin ortalamaları

\begin{tabular}{llcc}
\hline No & Maddeler & Ort. & SS \\
\hline 1 & e-Ögrenme sürecinde derslere işyerinden katllabilirim. & 3,87 & 1,278 \\
3 & e-Ögrenme sürecinde daha çok farkl-zamanlı etkinlikleri tercih & 3,54 & 1,196 \\
& ederim. & \\
2 & e-Öğrenme sürecinde daha çok eş-zamanlı etkinlikleri tercih ederim. & 3,37 & 1,309 \\
4 & Haftada en az 3-4 saat her bir derse sanal ortamda katılmak için & 3,33 & 1,320 \\
& & \\
\hline
\end{tabular}

Bulgulara göre, öğrencilerin e-öğrenme sürecine işyerlerinden veya okuldan katılmayı ve zaman esnekliğinin getirdiği farklı zamanlı etkinlikleri tercih ettikleri görülmektedir.

Ölçeğin beklenti boyutlarında ise başarıyı etkileyen faktörler boyutunun ortalama puanının ( $\bar{x}=3,92$; ss $=0,73)$, motivasyon ve tutum puanının ortalamasından $(\bar{x}=3,32$; $\mathrm{ss}=0,89)$ daha yüksek olduğu görülmektedir.

Tablo 6. Başarıyı etkileyen faktörler alt-boyutu maddelerinin ortalamaları

\begin{tabular}{|c|c|c|c|}
\hline No & Maddeler & Ort. & SS \\
\hline 22 & $\begin{array}{l}\text { Teknik ve idari konularda hızlı destek alabilmek başarım açısından çok } \\
\text { önemlidir. }\end{array}$ & 4,29 & ,860 \\
\hline 21 & Eğitmenle sürekli iletişim içinde olmak başarı açısından önemlidir. & 4,28 & 881 \\
\hline 25 & $\begin{array}{l}\text { Görsel-işitsel materyalleri kullanarak öğrenmem gereken bilgi ve } \\
\text { becerileri kazanacağımı düşünüyorum. }\end{array}$ & 3,99 & 1,005 \\
\hline 23 & e-Öğrenme sürecine sık katılım başarılı olmam açısmndan önemlidir. & 3,95 & 1,215 \\
\hline 24 & $\begin{array}{l}\text { e-Öğrenme sürecinde İnternet teknolojilerine ilişkim deneyimin } \\
\text { başarımı etkileyeceğini düşünüyorum. }\end{array}$ & 3,79 & 1,091 \\
\hline 26 & $\begin{array}{l}\text { İnternet ortamında diğer bireylerle rahatlikla tartışabileceğimi } \\
\text { düşünüyorum. }\end{array}$ & 3,37 & 1,274 \\
\hline
\end{tabular}

Tablo 6'da da görüldüğü gibi, başarıyı etkileyen faktörler alt-boyutunda en yüksek puanı alan teknik ve idari konularda hızlı destek alabilme ve eğitmenle sürekli iletişim içerisinde olabilme, öğrenciler tarafından e-öğrenme ortamlarında başarıyı en fazla etkileyen faktörler olarak kendini göstermektedir.

Tablo 7. Motivasyon ve Tutum Alt-Boyutu Maddelerinin Ortalamaları

\begin{tabular}{llcc}
\hline No & Maddeler & Ort. & SS \\
\hline 17 & $\begin{array}{l}\text { Eğitmenle eş-zamanlı etkileşim kuramasam bile tek başıma rahatllkla } \\
\text { çalşabileceğimi düşünüyorum. }\end{array}$ & 3,51 & 1,164 \\
19 & $\begin{array}{l}\text { Ders çalıştı̆ım ortamda çok fazla dikkat dağı̆ııı olmasına rağmen } \\
\text { çalışmalarımı zamanında tamamlayacağımı düşünüyorum. }\end{array}$ & 3,42 & 1,183 \\
18 & $\begin{array}{l}\text { İnternet ortamında çok fazla dikkat dağtıcı olmasina rağmen } \\
\text { çalışmalarımı zamanında tamamlayacağımı düşünüyorum. }\end{array}$ & 3,34 & 1,247 \\
20 & e-Öğrenme yöntemi ile çok iyi öğrenebileceğimi düşünüyorum. & 3,05 & 1,287 \\
\hline
\end{tabular}


Tablo 7'de ifade edildiği üzere, başarıyı etkileyen faktörler alt-boyutunda yer alan maddeler, öğrencilerin kendi kendilerine çalışabilmeleri ve öğrenmelerinin sorumluluğunu alabilmeleri ile ilgilidir. Bu alt-boyuttan alınan puanlar, öğrencilerin nötr bir tutum izlediklerini göstermektedir.

Bilgisayar Mühendisliği ve İnşaat Mühendisliği bölümlerine devam eden öğrencilerin bölümlere göre e-Öğrenme Sürecine İlişkin Hazır Bulunuşluk ve Beklenti Ölçeği’nden aldıkları genel ve boyut bazlı ortalama puanları arasında görülen bu farklılıkların anlamlı olup olmadığını belirlemek için istatistiksel analiz yapılmıştır. Analiz sonuçları Tablo 8 'de verilmektedir.

Tablo 8. Bölümlere göre hazır bulunuşluk ve beklenti ölçeğinden alınan ortalama puan farklar1

\begin{tabular}{|c|c|c|c|c|c|c|c|}
\hline Boyutlar & Bölümler & $\mathbf{N}$ & $\mathbf{X}$ & SS & Sd & $\mathbf{t}$ & $\mathbf{p}$ \\
\hline \multirow[t]{2}{*}{ KÖ } & İnşaat Müh. & 65 & 3,45 & ,975 & 97.68 & -1.170 & .25 \\
\hline & Bilgisayar Müh. & 37 & 3,64 & 644 & & & \\
\hline \multirow[t]{2}{*}{ TE } & İnşaat Müh. & 65 & 4,20 & 1,026 & 100 & -1.092 & 0.28 \\
\hline & Bilgisayar Müh. & 37 & 4,41 & ,715 & & & \\
\hline \multirow[t]{2}{*}{ TB } & İnşaat Müh. & 65 & 4,32 & 834 & 100 & $-1,576$ & .08 \\
\hline & Bilgisayar Müh. & 37 & 4,56 &, 543 & & & \\
\hline \multirow[t]{2}{*}{ MvT } & İnşaat Müh. & 65 & 3,28 & ,932 & 100 & -0.608 & .54 \\
\hline & Bilgisayar Müh. & 37 & 3,39 & ,828 & & & \\
\hline \multirow[t]{2}{*}{ BEF } & İnşaat Müh. & 65 & 3,92 & ,758 & 100 & 0.087 & .93 \\
\hline & Bilgisayar Müh. & 37 & 3,91 & 687 & & & \\
\hline
\end{tabular}

Tablo 8 incelendiğinde e-Öğrenme Sürecine İlişkin Hazır Bulunuşluk ve Beklenti Ölçeği'nden aldıkları genel ve boyut bazlı ortalama puanları arasında bölümlere göre istatistiksel olarak anlamlı bir farklılık bulunamamıştır [KÖ t(97,68)=-1.170; $>$ >05], [TE $\mathrm{t}(100)=-1,092 ; \mathrm{p}>.05],[\mathrm{TB} \mathrm{t}(100)=-1,576 ; \mathrm{p}>.05],[\mathrm{MvT} \mathrm{t}(100)=-0,608 ; \mathrm{p}>.05],[\mathrm{BEF}$ $\mathrm{t}(100)=.087 ; \mathrm{p}>.05]$. Bölümler arasında istatistiksel olarak anlamlı bir fark olmamasına rağmen, Bilgisayar Mühendisliği ve İnşaat Mühendisliği öğrencilerinin ölçekten aldıkları puanların aritmetik ortalamalarına bakıldığında, ölçeğin Başarıyı Etkileyen Faktörler boyutu dışındaki tüm boyutlarda ve toplamda Bilgisayar Mühendisliği Bölümü öğrencilerinin puanlarının daha yüksek olduğu görülmektedir.

Öğrencilerin Öğrenme Sürecine İlişkin Hazır Bulunuşluk ve Beklenti Ölçeği’nden aldıkları ortalama puanları cinsiyet değişkenine göre hiçbir boyutta anlamlı olarak farklılaşmamaktadır [KÖ t $(100)=-0.162 ; \mathrm{p}>.05]$, [TE $\mathrm{t}(100)=0,072 ; \mathrm{p}>.05]$ ], [TB $\mathrm{t}(100)=-$ $0,365 ; \mathrm{p}>.05],[\operatorname{MvT~t}(100)=1,114 ; \mathrm{p}>.05],[\operatorname{BEF} \mathrm{t}(100)=0,855 ; \mathrm{p}>.05]$. 
Tablo 9. Cinsiyete göre hazır bulunuşluk ve beklenti ölçeğinden alınan ortalama puan farklar1

\begin{tabular}{|c|c|c|c|c|c|c|c|}
\hline Boyutlar & Cinsiyet & $\mathbf{N}$ & $\mathbf{X}$ & SS & Sd & $\mathbf{t}$ & $\mathbf{p}$ \\
\hline \multirow[t]{2}{*}{ KÖ } & Kadın & 21 & 4,25 & ,652 & 100 & -0.162 & .87 \\
\hline & Erkek & 81 & 4,29 & ,989 & & & \\
\hline \multirow[t]{2}{*}{ TE } & Kadın & 21 & 4,25 & ,652 & 100 & -0.162 & .87 \\
\hline & Erkek & 81 & 4,29 & ,989 & & & \\
\hline \multirow[t]{2}{*}{ TB } & Kadın & 21 & 4,36 & ,596 & 100 & -0.365 & .72 \\
\hline & Erkek & 81 & 4,42 & ,786 & & & \\
\hline \multirow[t]{2}{*}{ MvT } & Kadın & 21 & 3,51 & ,871 & 100 & 1.114 & .27 \\
\hline & Erkek & 81 & 3,27 & ,898 & & & \\
\hline \multirow[t]{2}{*}{ BEF } & Kadın & 21 & 4,04 & ,685 & 100 & 0.855 & .39 \\
\hline & Erkek & 81 & 3,89 & ,741 & & & \\
\hline
\end{tabular}

Tablo 9'a göre kadın ve erkek öğrenciler arasında istatistiksel olarak anlamlı bir fark olmamasına rağmen, kişilik özellikleri ve teknolojik beceriler boyutlarında erkek öğrencilerin ortalama puanları göreceli olarak kadın öğrencilerden daha fazla bulunurken, teknolojiye erişim, motivasyon ve tutum ve başarıyı etkileyen faktörler boyutlarında kadınların ortalamaları erkeklere göre göreceli olarak daha fazladır.

Öğrencilerin uzaktan eğitim yöntemiyle ders alma durumuna göre e-Öğrenme Sürecine İlişkin Hazır Bulunuşluk ve Beklenti Ölçeği’nden aldıkları genel ve boyut bazlı ortalama puanları arasındaki farklara t testi ile bakılmış olup istatistiksel olarak anlamlı bir farklılık bulunamamıştır [KÖ $\mathrm{t}(100)=0,418 ; \mathrm{p}>.05$ ], [TE $\mathrm{t}(100)=-0,657 ; \mathrm{p}>.05$ ], [TB $\mathrm{t}(100)=-0,628 ; \mathrm{p}>.05],[\operatorname{MvT~t}(100)=0,212 ; \mathrm{p}>.05],[\operatorname{BEF~t}(100)=1,061 ; \mathrm{p}>.05]$.

Gruplar arasında istatistiksel olarak anlamlı bir fark olmamasına rağmen, teknolojiye erişim ve kişisel özellikler boyutları dışındaki diğer tüm boyutlarda daha önceden uzaktan eğitim yöntemiyle ders almış olan öğrencilerin ortalama puanlarının, uzaktan eğitime maruz kalmamış öğrencilere göre göreceli olarak daha fazla olduğu görülmektedir (Bkz. Tablo 10).

Tablo 10. Uzaktan eğitim yöntemiyle ders alma durumuna göre hazır bulunuşluk ve beklenti ölçeğinden alınan ortalama puan farkları

\begin{tabular}{|c|c|c|c|c|c|c|c|}
\hline Boyutlar & $\begin{array}{l}\text { Uzaktan Eğitim Yöntemiyle } \\
\text { Ders Alma Durumu }\end{array}$ & $\mathbf{N}$ & $\mathbf{X}$ & SS & Sd & $\mathbf{t}$ & $\mathbf{p}$ \\
\hline \multirow[t]{2}{*}{ KÖ } & Evet & 89 & 2,46 & 0,641 & 100 & 0,418 & 0,667 \\
\hline & Hayır & 13 & 2,54 & 0,519 & & & \\
\hline \multirow[t]{2}{*}{ TE } & Hayir & 89 & 2,74 & ,554 & 100 & -0.657 & .51 \\
\hline & Hayır & 13 & 2,85 & ,376 & & & \\
\hline \multirow[t]{2}{*}{ TB } & Evet & 89 & 4,43 & 751 & 100 & 0.628 & .53 \\
\hline & Hayir & 13 & 4,29 & ,744 & & & \\
\hline \multirow[t]{2}{*}{ MvT } & Evet & 89 & 3,33 & ,886 & 100 & 0.212 & .83 \\
\hline & Hayir & 13 & 3,27 & 981 & & & \\
\hline \multirow[t]{2}{*}{ BEF } & Evet & 89 & 3,95 & ,709 & 100 & 1.061 & .29 \\
\hline & Hayır & 13 & 3,72 & 859 & & & \\
\hline
\end{tabular}




\subsection{Memnuni yet Bulguları}

Memnuniyet anketinin altı alt boyutu bulunmaktadır: Tartışma Grupları ve Forumları Kullanma (TFK), Eğitmen ve Öğrenciler Arasındaki Diyalog (EÖD), Çevrimiçi Deneyim Algısı (ÇDA), Eğitmen Özellikleri (EÖ), Öğrenme Topluluğu Hissi (ÖTH) ve Bilgisayar Destekli İletişim'dir (BDİ). Boyutların tamamı değerlendirildiğinde, ankete verilen yanıtların ortalama puanın 2,95 olması öğrencilerin e-öğrenme deneyimlerinden memnuniyet düzeylerinin ortalamanın altında olduğunu göstermektedir $(\bar{x}=2,95$; ss $=0,88)$. Bu memnuniyet düzeyinde etkili olan faktörlerin değerlendirilmesi için anketin boyutlarına bakıldı̆̆ında, en çok tartışma grupları ve forumların kullanımı ( $\bar{x}=3,23$; ss $=1,09)$ ile eğitmen özellikleri $(\bar{x}=3,15 ; \mathrm{ss}=1,05)$ boyutlarında öğrencilerin puanlarının ortalamanın üzerinde olduğu görülmüştür. Tüm katılımcılar için ölçeğin alt-boyutlarına göre madde ortalamaları ve yorumları aşağıda verilmiştir.

Tablo 11. Tartışma grupları ve forumların kullanımı (TFK) alt-boyutu madde ortalamaları

\begin{tabular}{|c|c|c|c|}
\hline $\mathrm{Nc}$ & Maddeler & Ort. & SS \\
\hline & \multicolumn{3}{|l|}{ Çevrimiçi öğrenme deneyimimden memnunum; çünkü... } \\
\hline 2 & $\begin{array}{l}\text { Asenkron tartı̧malar (yani görüşlerimi günün herhangi bir anında } \\
\text { gönderebilme esnekliğine sahip olmam) zaman açısından sınıf içi } \\
\text { tartsşmalardan daha uygundu. }\end{array}$ & 3,26 & 1,290 \\
\hline 3 & $\begin{array}{l}\text { Çevrimiçi tartsşmalara yazacaklarımı iyice düşünüp taslak halinde } \\
\text { yazabilmek için yeterli vaktim oluyor. }\end{array}$ & 3,23 & 1,292 \\
\hline 1 & $\begin{array}{l}\text { Tartışma grupları ve forumlarda görüş bildirmek sınıf içerisinde } \\
\text { olduğundan daha rahattı. }\end{array}$ & 3,20 & 1,243 \\
\hline
\end{tabular}

Tablo 11'de görüldüğü gibi öğrenciler, tartışma gruplarının gerçek zamanlı olmamasının avantajlarını vurgulamışlardır.

Tablo 12. Eğitmen özellikleri (EÖ) alt-boyutu madde ortalamaları

\begin{tabular}{llcc}
\hline No & Maddeler & Ort. & SS \\
\hline & Çevrimiçi öğrenme deneyimimden memnunum; çünkü ... & & \\
\hline 10 & $\begin{array}{l}\text { Çevrimiçi dersin eğitmeniyle yüz yüze dersin eğitmeninden aldı̆ım } \\
\text { bilgiler çok farklı değildir. }\end{array}$ & 3,46 & 1,253 \\
11 & $\begin{array}{l}\text { Çevrimiçi dersin eğitmeniyle yüz yüze dersin eğitmeni öğrenmeyle ilgili } \\
\text { sikıntılarıma aynı derecede yardımcı oluyorlar. }\end{array}$ & 3,08 & 1,277 \\
12 & $\begin{array}{l}\text { Teknoloji çevrimiçi ders eğitmenlerinin geleneksel smıtta olduğundan } \\
\text { daha yaratıcı bir şekilde öğretmelerini sağlıyor. }\end{array}$ & 2,91 & 1,407 \\
\hline
\end{tabular}

Tablo 12'de verilen eğitmen özellikleri ile ilgili maddeler incelendiğinde ise, öğrenciler eğitmenin çevrimiçi veya yüz yüze ders vermesinin kendilerine aktardıkları bilgiler açısından bir farklılık yaratmadığı ve öğrencilere aynı düzeyde destek sağladığına 
dair olumluya yakın görüş bildirmişlerdir. Öğrenciler, teknolojinin eğitmeni sınıfta daha yaratıcı kıldığg konusunda nötr düşünmektedir.

Boyutlar arasında üçüncü sırada eğitmen ve öğrenciler arasındaki diyalog yer almaktadır $(\bar{x}=3,01 ; \mathrm{s}=0,99)$. Tablo 13 'de görüldüğü gibi, öğrenciler ders süresince eğitmenle etkin bir şekilde iletişim kurabildikleri ve eğitmenleriyle sahip oldukları çevrimiçi diyalogun öğrenmeye etkisi konusunda nötr bir bakışa sahiptir.

Tablo 13. Eğitmen ve öğrenciler arasındaki diyalog (EÖD) alt-boyutu madde ortalamaları

\begin{tabular}{llcc}
\hline No & Maddeler & Ort. & SS \\
\hline 4 & $\begin{array}{l}\text { Çevrimiçi öğrenme deneyimimden memnunum; çünkü dönem boyunca } \\
\text { eğitmenimle etkin bir şekilde iletişim kurabildim. }\end{array}$ & 3,13 & 1,178 \\
5 & $\begin{array}{l}\text { Çevrimiçi öğrenme deneyimimden memnunum; çünkü eğitmenimle } \\
\text { girdiğim çevrimiçi diyalog derste daha iyi öğrenmemi sağladı. }\end{array}$ & 3,01 & 1,216 \\
6 & $\begin{array}{l}\text { Çevrimiçi öğrenme deneyimimden memnunum; çünkü eğitmenimle } \\
\text { sürekli çevrimiçi diyalog içerisinde olduğumdan kendimi uzakta } \\
\text { hissetmiyorum. }\end{array}$ & 2,92 & 1,117 \\
\hline
\end{tabular}

Bu boyuta çok yakın bir ortalama puana sahip olan $(\bar{x}=2,99 ; \mathrm{ss}=1,07)$ diğer boyut, Tablo 14'de görüldüğü gibi çevrimiçi deneyim algısı boyutudur. Öğrenciler bir öğrenci olarak gereksinimlerinin karşılanması anlamında çevrimiçi öğrenme deneyimlerine dair olumluya yakın bir görüşe sahip olsalar da, seçenekleri olduğu takdirde çevrimiçi ders alma konusunda tereddütlüdürler.

Tablo 14. Çevrimiçi deneyim algısı (ÇDA) alt-boyutu madde ortalamaları

\begin{tabular}{llcc}
\hline No & Maddeler & Ort. & SS \\
\hline 7 & $\begin{array}{l}\text { Çevrimiçi öğrenme deneyimimden memnunum; çünkü bir öğrenci } \\
\text { olarak kişisel ihtiyaçlarım çevrimiçi ortamda karşınlanabiliyor. } \\
8\end{array}$ & 3,19 & 1,232 \\
$\begin{array}{l}\text { Çevrimiçi öğrenme deneyimimden memnunum; çünkü bir öğrenci } \\
\text { olarak çevrimiçi öğrenmenin birçok özelliğini seviyorum. }\end{array}$ & 3,17 & 1,310 \\
$\quad \begin{array}{l}\text { Cevrimiçi öğrenme deneyimimden memnunum; çünkü genelde yüz } \\
\text { yüze dersler yerine çevrimiçi ders almayı tercih ediyorum. }\end{array}$ & 2,61 & 1,363 \\
\hline
\end{tabular}

Memnuniyet ölçeğinden en düşük ortalama puanı alan iki boyut, sırasıyla Tablo 15 ve Tablo 16'da görüldüğü üzere Öğrenme Topluluğu Hissi ( $\bar{x}=2,65$; ss=1,17) ve Bilgisayar Destekli İletişim $(\bar{x}=2,64 ;$ ss=1,17) boyutlarıdır. Aşağıdaki tablolarda da görüldüğü gibi öğrenciler çevrimiçi öğrenmenin sınıf arkadaşlarıyla iletişim içerisinde olacakları, birlikte çalışacakları ve paylaşacakları bir ortam sağladığı konusunda neredeyse olumsuz bir tutuma sahiptir. Yanıtlar nötre yakın olsa da, öğrencilerin kendilerini bir topluluğun parçası olarak hissetmediklerini göstermektedir. 
Tablo 15. Öğrenme topluluğu hissi (ÖTH) alt-boyutu madde ortalamaları

\begin{tabular}{llcc}
\hline No & Maddeler & Ort. & SS \\
\hline 13 & $\begin{array}{l}\text { Çevrimiçi öğrenme deneyimimden memnunum; çünkü çevrimiçi ortam } \\
\text { diğer öğrencilerle iletişim kurabileceğim bir grup içerisinde olduğumu } \\
\text { hissettiriyor. }\end{array}$ & 2,74 & 1,323 \\
15 & $\begin{array}{l}\text { Çevrimiçi öğrenme deneyimimden memnunum; çünkü çevrimiçi } \\
\text { öğrenme ortamı, smiftaki diğer öğrencilerle birlikte çalısırken kendimi } \\
\text { iyi hissettiğim güvenli bir ortamdır. } \\
\begin{array}{l}\text { Çevrimiçi öğrenme deneyimimden memnunum; çünkü çevrimiçi } \\
\text { öğrenmenin öğrenciler arasmda paylaşımı artırdı̆ğna inanıyorum. }\end{array}\end{array}$ & 2,67 & 1,267 \\
\hline
\end{tabular}

Tablo 16. Bilgisayar Destekli İletişim (BDI) alt-boyutu madde ortalamaları

\begin{tabular}{clcc}
\hline No & Maddeler & Ort. & SS \\
\hline 17 & $\begin{array}{l}\text { Çevrimiçi öğrenme deneyimimden memnunum; çünkü bilgisayar destekli iletişim } \\
\text { ile çevrimiçi ortamdaki öğrencilerle anlamlı ilişkiler kurmak daha kolay oluyor. }\end{array}$ & 2,72 & 1,294 \\
18 & $\begin{array}{l}\text { Çevrimiçi öğrenme deneyimimden memnunum; çünkü bilgisayar destekli iletişim } \\
\text { ile çevrimiçi ortamda eğitmenimin ve sınıf arkadaşlarımın varlı̆ını hissetmek }\end{array}$ & 2,64 & 1,368 \\
& $\begin{array}{l}\text { mümkün oluyor. } \\
\text { Çevrimiçi öğrenme deneyimimden memnunum; çünkü bilgisayar destekli iletişim } \\
\text { ile çevrimiçi ortamda iletişime geçtiğimde kendimi gerçek bir kişi gibi } \\
\text { hissediyorum. }\end{array}$ & 2,58 & 1,199 \\
\hline
\end{tabular}

Bilgisayar Mühendisliği ve İnşaat Mühendisliği bölümlerine devam eden öğrencilerin bölümlere göre Çevrimiçi Öğrenme Memnuniyet Ölçeği'nden aldıkları ortalama puanları arasındaki farkların anlamlı olup olmadığını belirlemek için t-testi yapılmıştır. Analiz sonuçları aşağıdaki tablo ile verilmektedir.

Tablo 17. Bölümlere göre memnuniyet ölçeğinden alınan ortalama puan farkları

\begin{tabular}{|c|c|c|c|c|c|c|c|}
\hline Boyutlar & Bölüm & $\mathbf{N}$ & $\mathbf{X}$ & SS & Sd & $\mathbf{t}$ & $\mathbf{p}$ \\
\hline \multirow[t]{2}{*}{ TFK } & Bilgisayar Müh. & 41 & 9,95 & 3,07 & 93 & 661 &, 510 \\
\hline & Inşaat Müh. & 54 & 9,50 & 3,46 & & & \\
\hline \multirow[t]{2}{*}{ EÖD } & Bilgisayar Müh. & 41 & 9,29 & 2,75 & 93 & 682 & 497 \\
\hline & İnşaat Müh. & 54 & 8,87 & 3,16 & & & \\
\hline \multirow[t]{2}{*}{ ÇDA } & Bilgisayar Müh. & 41 & 9,09 & 3,01 & 93 & ,340 & ,735 \\
\hline & İnşaat Müh. & 54 & 8,87 & 3,38 & & & \\
\hline \multirow[t]{2}{*}{ EÖ } & Bilgisayar Müh. & 41 & 9,63 & 2,91 & 93 & ,486 & 628 \\
\hline & İnşaat Müh. & 54 & 9,31 & 3,36 & & & \\
\hline \multirow[t]{2}{*}{ ÖTH } & Bilgisayar Müh. & 41 & 8,36 & 3,38 & 93 & 1,012 & ,314 \\
\hline & İnşaat Müh. & 54 & 7,62 & 3,61 & & & \\
\hline \multirow[t]{2}{*}{ BDİ } & Bilgisayar Müh. & 41 & 7,97 & 3,03 & 93 & ,093 & ,926 \\
\hline & İnşaat Müh. & 54 & 7,90 & 3,87 & & & \\
\hline
\end{tabular}


Tablo incelendiğinde Bilgisayar Mühendisliği ve İnşaat Mühendisliği bölümlerine devam eden öğrencilerin bölümlere göre Çevrimiçi Öğrenme Memnuniyet Ölçeği’nden aldıkları ortalama puanlarına bakılarak istatistiksel olarak anlamlı bir farklılık bulunmadığı tespit edilmiştir [TFK $\mathrm{t}(93)=.66 ; \mathrm{p}>.05$ ], [EÖD $\mathrm{t}(93)=.68 ; \mathrm{p}>.05$ ], [ÇDA $\mathrm{t}(93)=.34 ; \mathrm{p}>.05],[$ EÖ $\mathrm{t}(93)=.49 ; \mathrm{p}>.05]$ ], [ÖTH $\mathrm{t}(93)=1.01 ; \mathrm{p}>.05]$, [BDİ $\mathrm{t}(93)=.09$; $\mathrm{p}>$.05]. Bölümler arasında istatistiksel olarak anlamlı bir fark olmamasına rağmen Bilgisayar Mühendisliği ve İnşaat Mühendisliği öğrencilerinin ölçekten aldıkları puanların aritmetik ortalamalarına bakıldığında, hem boyutlar bazında hem de toplamda Bilgisayar Mühendisliği Bölümü öğrencilerinin puanlarının daha yüksek olduğu görülmektedir.

Tablo 18. Cinsiyete Göre Memnuniyet Ölçeğinden Alınan Ortalama Puan Farkları

\begin{tabular}{|c|c|c|c|c|c|c|c|}
\hline Boyutlar & Cinsiyet & $\mathbf{N}$ & $\mathbf{X}$ & SS & Sd & $\mathbf{t}$ & $\mathbf{p}$ \\
\hline \multirow{2}{*}{ TFK } & Erkek & 74 & 9,89 & 3,13 & \multirow[t]{2}{*}{93} & \multirow[t]{2}{*}{1,099} & \multirow[t]{2}{*}{,274 } \\
\hline & Kadın & 21 & 9,00 & 3,78 & & & \\
\hline \multirow{2}{*}{ EÖD } & Kadın & 74 & 9,19 & 2,86 & \multirow[t]{2}{*}{93} & \multirow{2}{*}{,837 } & \multirow{2}{*}{ 405 } \\
\hline & Erkek & 21 & 8,57 & 3,38 & & & \\
\hline \multirow[t]{2}{*}{ ÇDA } & Kadın & 74 & 9,39 & 3,05 & \multirow[t]{2}{*}{93} & \multirow[t]{2}{*}{2,478} & \multirow[t]{2}{*}{,015 } \\
\hline & Erkek & 21 & 7,48 & 3,38 & & & \\
\hline \multirow[t]{2}{*}{ EÖ } & Kadın & 74 & 9,45 & 3,26 & \multirow[t]{2}{*}{93} & \multirow[t]{2}{*}{,- 038} & \multirow[t]{2}{*}{,969 } \\
\hline & Erkek & 21 & 9,48 & 2,87 & & & \\
\hline \multirow[t]{2}{*}{ ÖTH } & Kadın & 74 & 8,16 & 3,49 & \multirow[t]{2}{*}{93} & \multirow{2}{*}{1,120} & \multirow{2}{*}{,266 } \\
\hline & Erkek & 21 & 7,19 & 3,56 & & & \\
\hline \multirow[t]{2}{*}{ BDİ } & Kadın & 74 & 8,01 & 3,52 & \multirow[t]{2}{*}{93} & \multirow{2}{*}{,397 } & \multirow{2}{*}{ 692 } \\
\hline & Erkek & 21 & 7,67 & 3,58 & & & \\
\hline
\end{tabular}

Çevrimiçi Öğrenme Memnuniyet Ölçeği'nin Deneyim Algısı alt boyutu dışındaki genel ve diğer boyutlarından alınan ortalama puanlar cinsiyet değişkenine göre farklılaşmamaktadır [TFK $\mathrm{t}(93)=1.099 ; \mathrm{p}>.05$ ], [EÖD $\mathrm{t}(93)=.837 ; \mathrm{p}>.05$ ], [ÇDA $\mathrm{t}(93)=2.478 ; \mathrm{p}<.05],[$ EÖ $\mathrm{t}(93)=-.038 ; \mathrm{p}>.05]$, [ÖTH $\mathrm{t}(93)=1.120 ; \mathrm{p}>.05]$, [BDİ $\mathrm{t}(93)=.397 ; \mathrm{p}>.05]$. Çevrimiçi Deneyim algısı (ÇDA) alt boyutunda da gözlemlenen farklılığın erkek öğrenciler lehine olduğu tespit edilmiştir $\left(\bar{x}_{\text {erkek }}=9,39 ; \mathrm{SS}=3,05\right.$ ve $\bar{x}$ kadin $=7,47 ; \mathrm{SS}=3,38$ ).

Öğrencilerin uzaktan eğitim yöntemiyle ders alma durumuna göre e-Öğrenme Sürecine İlişkin Memnuniyet Ölçeği’nden aldıkları genel ve boyut bazlı ortalama puanları arasındaki farklılık t testi ile bakılmış olup istatistiksel olarak anlamlı bir farklılık bulunamamıştır [TFK $\mathrm{t}(93)=0.911 ; \mathrm{p}>.05$ ], [EÖD $\mathrm{t}(93)=1.071 ; \mathrm{p}>.05$ ], [ÇDA $\mathrm{t}(93)=1.458$; $\mathrm{p}<.05$ ], [EÖ $\mathrm{t}(93)=1.028 ; \mathrm{p}>.05$ ], [ÖTH $\mathrm{t}(93)=0.961 ; \mathrm{p}>.05$ ], [BDİ $\mathrm{t}(93)=0.778 ; \mathrm{p}>.05$ ]. 
Tablo 19. Uzaktan eğitim yöntemiyle ders alma durumuna göre memnuniyet ölçeğinden alınan ortalama puan farkları

\begin{tabular}{|c|c|c|c|c|c|c|c|}
\hline Boyutlar & $\begin{array}{l}\text { Uzaktan Eğitim } \\
\text { Yönte miyle De rs } \\
\text { Alma Durumu }\end{array}$ & $\mathbf{N}$ & $\mathbf{X}$ & SS & Sd & $\mathbf{t}$ & $\mathbf{p}$ \\
\hline \multirow{2}{*}{ TFK } & Evet & 82 & 9,81 & 3,20 & 93 & ,911 & ,365 \\
\hline & Hayır & 13 & 8,92 & 3,82 & & & \\
\hline \multirow[t]{2}{*}{ EÖD } & Evet & 82 & 9,18 & 2,99 & 93 & 1,071 & 287 \\
\hline & Hayır & 13 & 8,23 & 2,89 & & & \\
\hline \multirow{2}{*}{ ÇDA } & Evet & 82 & 9,16 & 3,22 & 93 & 1,458 & 148 \\
\hline & Hayır & 13 & 7,77 & 2,98 & & & \\
\hline \multirow[t]{2}{*}{ EÖ } & Evet & 82 & 9,59 & 3,17 & 93 & 1,028 & ,307 \\
\hline & Hayır & 13 & 8,62 & 3,12 & & & \\
\hline \multirow[t]{2}{*}{ ӦTH } & Evet & 82 & 8,09 & 3,55 & 93 & 961 & ,339 \\
\hline & Hayır & 13 & 7,08 & 3,28 & & & \\
\hline \multirow[t]{2}{*}{ BDİ } & Evet & 82 & 8,05 & 3,58 & 93 & ,778 & 439 \\
\hline & Hayır & 13 & 7,23 & 3,14 & & & \\
\hline
\end{tabular}

Gruplar arasında istatistiksel olarak anlamlı bir fark olmamasına rağmen, tüm alt boyutlarda ve toplamda uzaktan eğitim yöntemi ile ders alanların ortalama puanları almayanlara oranla daha fazladır $\left[\bar{x}_{\mathrm{TFK}}=9,82 ; \mathrm{SS}=3,20\right], \quad\left[\bar{x}_{\mathrm{EÖD}}=9,18 ; \mathrm{SS}=2,99\right.$, $\left[\bar{x}_{\mathrm{CDA}}=9,15 ; \mathrm{SS}=3,22\right],\left[\bar{x}_{\mathrm{EÖ}}=9,58 ; \mathrm{SS}=3,16\right],\left[\bar{x}_{\text {Ӧт }}=8,08 ; \mathrm{SS}=3,54\right],\left[\bar{x}_{\mathrm{BDi}}=8,04\right.$; $\mathrm{SS}=3,57]$.

\section{Tartışma ve Sonuç}

Geleneksel öğrenme ortamlarının giderek elektronik öğrenme ortamlarına dönüştüğü günümüzde, belli bir disiplinden bağımsız olarak birçok alan dersi çevrimiçi teknolojiler kullanılarak verilmektedir. Öğrencilerin bu yeni öğrenme ortamlarına ve yenilikçi öğrenme-öğretme yaklaşımlarına dair hazır bulunuşluklarının, beklentilerinin ve memnuniyetlerinin değerlendirilmesi, öğrenme ortamlarının niteliği, etkililiği ve verimliliği açısından son derece önemlidir.

Bilgisayar ve İnşaat Mühendisliği bölümlerine devam etmekte olan birinci sınıf öğrencilerini kapsayan bu araştırmada, öğrencilerin e-öğrenme ortamlarında eğitim alabilecek kişisel özelliklere sahip olduklarına, teknolojiye erişim imkânlarının oldukça yüksek ve e-öğrenme için gerekli teknik becerilere yeterince sahip olduklarına inandıkları söylenebilir. Öğrencilerin e-öğrenme sürecine yönelik motivasyonları ve başarılı olabileceklerine dönük düşünceleri da oldukça olumludur. Dolayısıyla, öğrencilerin genel olarak e-öğrenmeye hazır bulunuşluk düzeylerinin oldukça yüksek olduğu sonucuna varılabilir. Benzer bir bulgu, Korkmaz, Çakır ve Tan (2015) tarafından yapılan çalışmada da ortaya koyulmuştur. Araştırmacıların çalışması kapsamında yer alan öğrenciler de, eöğrenme sürecine uygun kişisel özelliklere sahip olduklarına inanmaktadırlar. 
Teknik ve idari konularda hızlı destek alabilme ve eğitmenle sürekli iletişim içerisinde olabilme, öğrenciler tarafından e-öğrenme ortamlarında başarıyı en fazla etkileyen faktörler olarak kendini göstermektedir. Teknik konularda hızlı destek gereksinimi öğrencilerin en çok önem verdiği teknolojiye erişim boyutuyla paralel olarak değerlendirilebilir; ayrıca, öğrencilerin kurumsal anlamda kendilerini dışlanmış hissetmemeleri ve sınıf içerisinde de eğitmenin varlığını hissederek onunla sürekli iletişim içerisinde olabilmelerinin önemi de öğrencilerin yanıtlarında vurgulanmaktadır. Bu vurgu, öğrencilerin memnuniyete ilişkin görüşlerinde de kendini göstermektedir. Öğrenciler çevrimiçi öğrenme ortamının sağladığı bilgisayar destekli iletişim olanağını arkadaşlarının ve eğitmenlerinin sınıf içerisindeki varlığını hissetmeleri ve gerçek bir kişi gibi anlamlı ilişkiler kurmaları için yeterli görmemekte, kendilerini bir topluluğun parçası olarak hissetmediklerine işaret etmektedir.

Öğrenciler sosyal paylaşım ortamlarını rahatlıkla kullanabildiklerini ifade etmiş olmalarına rağmen, İnternet ortamında diğer bireylerle rahatlıkla tartışabilecekleri konusunda neredeyse nötr bir görüşe sahiptirler; dolayısıyla sahip oldukları bu becerinin e-öğrenme ortamlarında kendilerine fayda sağlayabilecek bir artı değer olduğunun farkında olmadıkları söylenebilir. Benzer şekilde, öğrencilerin İnternet teknolojilerine ilişkin deneyimlerinin e-öğrenme ortamlarındaki başarılarını etkileyeceğini düşünmedikleri görülmektedir. Öğrencilerin bu farkındalığa sahip olmaları için, çevrimiçi ders veya programlara kayit olduktan sonra detaylı bir oryantasyon ve bilgilendirme sürecinden geçmeleri gerekmektedir.

Öğrenciler, derslere güçlü bir İnternet bağlantısı ve kuvvetli donanıma sahip bir bilgisayar kullanmak suretiyle evlerinden veya herhangi bir yerden bağlanmayı tercih etmektedirler. Çevrimiçi öğrenme sürecinde kullanılan bilgisayar teknolojilerinin ve internetin kalitesi gibi unsurların öğrencilerin hazır bulunuşluklarını etkilediği birçok çalışmada da ortaya koyulmuştur (Eom, 2014; İlhan ve Çetin, 2013; Shee \& Wang, 2008; Sun, Tsai, Finger, Chen \& Yeh, 2008; Wu, Tennyson \& Hsia, 2010). Buna ek olarak şunu söylemek de mümkündür: Katılımcıların beklentileri, motivasyon ve tutumlarına dair durumlardan daha çok başarıyı etkileyen unsurlardan etkilenmektedir. Yapılan diğer bazı çalışmalar da bu bulguyu desteklemekte, teknolojiye erişim, teknik beceriler, motivasyon ve e-öğrenme ortamlarının kullanışlılığının öğrencilerin e-öğrenme ortamlarına hazır bulunuşluk düzeylerini etkiledikleri vurgulanmaktadır (Watkins ve ark., 2004).

Öğrencilerin e-öğrenmeden beklentilerinde cinsiyete, devam ettikleri bölüme veya daha önceden e-öğrenme deneyimine sahip olup olmalarına göre anlamlı bir farklılık bulunmadığı tespit edilmiştir. Bu bulgu, diğer çalışmaların yanı sıra, Paechter, Maier ve Macher'in (2010) Avusturya'da 2.196 öğrenciyle yürüttüğü çalışmada da cinsiyetin ve daha önceden e-ders almış olmanın öğrencilerin e-öğrenmeye yönelik beklenti, tercih ve memnuniyetleri üzerinde anlamlı bir farklılık yaratmadığı sonucuyla örtüşmektedir.

Cinsiyet açısından anlamlı bir farklılık bulunmamış olsa da, beklenti ölçeğinin kişilik özellikleri ve teknoloji becerileri boyutlarında erkek öğrencilerin ortalamaları kadın öğrencilerin ortalamalarından göreceli olarak daha yüksek bulunmuştur. Buna paralel olarak, Korkmaz ve arkadaşları (2015) bulguları da benzer bir sonucu ortaya koymuştur. 
Alanyazında erkek öğrencilerin kadın öğrencilere göre teknik beceriler konusunda daha fazla motivasyona sahip olduğunu ortaya koyan bazı çalışmalar da yer almaktadır (Blum, 1999; Karuppan, 2001). Bu çalışmada, kadınların teknolojiye erişim, motivasyon ve tutum, başarıyı etkileyen faktörler boyutlarındaki ortalamaları erkeklere göre göreceli olarak daha yüksek olduğu görülmüştür. Benzer şekilde anlamlı bir farklılık görülmese de, teknolojik beceriler, motivasyon ve tutum ile başarıyı etkileyen faktörler alt boyutlarında çevrimiçi teknolojiler kullanılarak uzaktan eğitim yöntemiyle ders almış olan öğrencilerin ortalama puanlarının daha önce uzaktan eğitime maruz kalmayan öğrencilerin puanlarına göre daha fazla olduğu tespit edilmiştir. Daha önceden bu yöntemle ders alan öğrencilerin teknolojik beceriler konusunda kendisine daha çok inanması, motivasyon ve tutumunun da daha yüksek olması beklenen bir unsurdur.

Çalışma kapsamında yer alan öğrencilerin e-öğrenme deneyimlerinden memnuniyet düzeylerinin ortalamanın altında olduğu görülmektedir. Bu memnuniyet düzeyinde etkili olan faktörlere bakıldığında, öğrencilerin asenkron tartışma grupları ve forumların sağladığı esnekliği vurguladıkları ve eğitmenin çevrimiçi veya yüz yüze ders vermesinin kendilerine aktardıkları bilgiler açısından bir farklılık yaratmadığını ifade ettikleri ortaya çıkmaktadır. Öğrencilerin olumsuza yakın görüş bildirdiği unsurlar, e-öğrenme ortamının sağladığı iletişim olanakları ve öğrenme topluluğu hissidir. Öğrenciler çevrimiçi ögrenmenin sınıf arkadaşlarıyla iletişim içerisinde olacakları, birlikte çalışacakları ve paylaşacakları bir ortam sağladığı konusunda neredeyse olumsuz bir tutuma sahiptir. Yanıtlar, öğrencilerin kendilerini bir topluluğun parçası olarak hissedemediklerini göstermektedir. Bunun nedeni, öğrencilerin çevrimiçi öğrenme ortamının sağladığı bilgisayar destekli iletişim olanağını arkadaşlarının ve eğitmenlerinin sınıf içerisindeki varlığını hissetmeleri ve gerçek bir kişi gibi anlamlı ilişkiler kurmaları için yeterli görmemeleridir. Dolayısıyla çevrimiçi öğrenme deneyimlerine dair olumluya yakın bir görüşe sahip olsalar da, seçenekleri olduğu takdirde çevrimiçi ders alma konusunda tereddütlüdürler.

Öğrencilerin e-öğrenme deneyimlerinden memnuniyet düzeylerinde cinsiyete, devam ettikleri bölüme veya daha önceden e-öğrenme deneyimine sahip olup olmalarına göre anlamlı bir farklılık bulunmadığı tespit edilmiştir. Bununla birlikte, e-öğrenme deneyimine sahip olan öğrencilerin e-öğrenme ortamlarından memnuniyetlerinin göreceli olarak daha yüksek olduğu ve yine erkek ögrencilerin kadın öğrencilere göre daha pozitif bir bakışları olduğu görülmektedir. Bazı araştırmalardaysa, kadınların erkeklere oranla daha yüksek memnuniyet düzeyine sahip oldukları doğrultusunda sonuçlar elde edilmiştir (Fredericksen, Pickett, Shea, Pelz \& Swan, 2000; Swan, Shea, Fredericksen, Pickett \& Pelz, 2000).

Öğrencilerin çevrimiçi öğrenme ortamlarından bekledikleri ve nasıl öğrenmek istediklerine yönelik tercihleri, ögrenme-öğretme sürecinin daha doğru yapılandırılmasına, öğrenme-öğretme sürecinde farklı yaklaşımlar sunulmasına ve e-öğrenmenin sağladığı zaman ve mekân esnekliğinin bağımsız ve kendi kendine öğrenme tercihi olmayan 
öğrenciler için bir dezavantaj olmasının önüne geçilmesine yönelik düzenlemeler yapılmasına katkı verecektir.

\section{5. Öneriler}

Araştırmanın sonuçları 1şı̆̆ında, sonraki çalışmalarda öğrencilerin hazır bulunuşluklarının ve memnuniyetlerinin gerekçelerinin daha derinlemesine anlaşılabilmesi ve daha ayrıntılı incelemeler yapılabilmesi için nitel verilerle de desteklenmesi tavsiye edilebilir. Öğrencilerin beklenti ve memnuniyetleri doğrultusunda öğretim içeriği zenginleştirilerek elektronik dersleri iyileştirici çalışmalar yapılması faydalı olacaktır. Nitekim, eğitim yaşantılarında olumlu e-öğrenme deneyimi edinen öğrencilerin e-öğrenme ortamlarından beklentileri ve memnuniyet ölçütleri, var olan ögrenme ortamlarının iyileştirilmesine katkı sağlayacaktır. Bu nedenle de, olumlu eöğrenme deneyimlerini artıracak nitelikli e-öğrenme fırsatlarının yaratılarak sürecin eğitim araştırmacıları tarafından takip edilmesi ülkemizdeki e-öğrenme çalışmalarının niteliğinin artırılmasına katkı sağlayacağı düşünülmektedir. 


\section{Profile of Engineering Undergraduates on Readiness and Satisfaction for E-Learning}

\section{Extended Abstract}

Age of information technology has changed the learning-teaching environments with its affordances on flexibility and variety. This change has included the rapid development of online learning which has altered the mode of delivery in higher education institutions and pushed them to set new organizational and pedagogical models (Tait, 2010). Online learning (or as recently called, open and distance learning) is used to define a teaching process where an instructor, learner, and teaching practice are brought together, but not within a limited restriction of time and space, through technology, which requires special planning for instructional and administrational arrangements (Aydın, 2011; Moore \& Kearsley, 2012; Simonson, Smaldino, Albright \& Zvacek, 2012). Turkey started online learning in 1996 with Middle East Technical University (METU)'s certificate programs, and continued with the opening of several graduate and certificate programs in different higher education institutions in the early 2000s. Today, many universities deliver associate, undergraduate, and graduate degrees online in Turkey; besides, many more deliver common core courses and some departmental courses online. The problem is that planning and design processes are generally focused on conventional face-to-face models being merely transferred to online learning environments, resulting in poor quality courses. Readiness, expectations, and satisfaction of learners are important both for instructors and other stakeholders since it immensely contributes to the improvement of the quality of online courses and programs.

This study aims to examine expectations, and readiness, and satisfaction levels of oncampus engineering students for a blended Calculus course, and to draw implications for course improvement, through quantitative measurement tools on the basis of gender, department, and prior exposure to online learning. The study uses the correlational survey method, trying "to identify the degree of the change between two or more variables" (Karasar, 1991, p. 81). The study was conducted at Muğla Sıtkı Koçman University during the 2013-2014 academic year spring semester. Calculus-II course was redesigned as a blended course where visual and interactive materials are used in virtual classes for certain topics throughout the semester for optimum benefits of the learners. Content of the course involves course notes, presentations, worksheets, exercise sheets, animations, web links, and activities loaded on the university's learning management system. Virtual classes were held in equipped studios, and recordings were added to the course page for viewing/reviewing later. Participants of the study are freshman students enrolled in computer and civil engineering departments and taking the compulsory Calculus course. An e-Readiness scale (Gülbahar, 2012a) was used to identify the participants' level of readiness for e-learning, comprised of 26 items classified under five dimensions, and an Online Learning Satisfaction Scale (Davis, 2014) was used to identify the participants' level of 
satisfaction from their e-learning process, comprised of 18 items classified under six dimensions. Descriptive and inferential statistics were used to analyze data on a statistical software.

Findings show that participants have access to sufficient technical infrastructure to followecourses, and proficiency in computer and Internet use plays an important part in participants' readiness. Participants feel comfortable with using social sharing platforms, Internet services, and web-based communication tools. Participants reflect a higher level of motivation and success in online learning environments. Findings show that success factors rather than motivation and attitude have a greater influence on expectancies from online learning. Participants indicate immediate administrative and technical support and regular communication with the instructors as important success factors, and have a relatively neutral standing for items related to self-study and self-regulation. They also do not consider their experience in Internet technologies having a role in their success in online learning environments. Similarly, although participants describe themselves as 'at ease' using social sharing environments, they have an almost neutral standing in engaging in comfortable discussions with other people via the Internet. Thus, it is possible to say that they are not aware of the added value of this skill they possess in online learning environments. An examination of expectancy and readiness findings as of department and gender does not indicate a significant difference between students enrolled in computer and civil engineering departments, and between male and female students. Participants have similar expectations from an online learning experience. Similarly, prior exposure to online learning also does not indicate a significant difference among students, yet scores of those students exposed to online learning previously are relatively higher for many items.

Level of satisfaction for participants' e-learning experience was measured from various perspectives including using discussion groups and forum, dialogue between instructor and learners, perceived online experience, instructor characteristics, learning community, and computer-assisted communication. Data analysis indicates that the participants are somewhat satisfied with their online learning experience with a total score slightly above average. An examination of satisfaction findings as of department and gender does not indicate a significant difference between students enrolled in computer and civil engineering departments, and between male and female students. Similarly, prior exposure to online learning also does not indicate a significant difference among students in terms of their level of satisfaction from online learning environment.

As a result, the study reveals that freshman engineering students have a high level of readiness for online learning, they are somewhat satisfied with the blended Calculus course, and this situation does not differ significantly as far as gender and enrolled department are concerned. Another finding from the study is that participants with prior exposure to online learning tend to be more satisfied with online learning experience. It would be valuable to support such studies about learners' reflections on their online learning experiences with qualitative methods for a more detailed insight and in-depth understanding of the phenomenon. Findings from these studies will help to improve the design, development and implementation of online courses and programs. Hence, creation of high-quality online learning opportunities to be followed and examined by educational researchers for further 
improvement will contribute to the eminence of online learning-teaching initiatives in Turkey.

\section{Kaynaklar/References}

Aydın, C. H. (2011). Açık ve uzaktan öğrenme: öğrenci adaylarının bakış açısı. Ankara: Pegem Akademi.

Bates, A. W. (2000). Distance education in dual mode higher education institutions: challenges and changes. Vancouver: University of British Columbia.

Beqiri, M. S., Chase, N. M., \& Bishka, A. (2009). Online course delivery: An empirical investigation of factors affecting student satisfaction. Journal of Education for Business, 85(2), 95-100.

Blair, R., Kirkman, E. E., \& Maxwell, J. W. (2013). Statistical abstract of undergraduate programs in the mathematical sciences in the United States. Washington D.C.: American Mathematical Society.

Blum, K. D. (1999). Gender differences in asynchronous learning in higher education: learning styles, participation barriers and communication. Journal of Asynchronous Learning Networks, 3(1), 46-66.

Borotis, S. A., \& Poulymenakou, A. (2004). E-learning readiness components: key issues to consider before adopting e-learning interventions. In J. Nall \& R. Robson (Eds.), Proceedings of e-learn: World conference on e-learning in corporate, government, healthcare and higher education 2004 (pp. 1622-1629). Chesapeake, VA: Association for the Advancement of Computing in Education (AACE).

Bray, E., Aoki, K., \& Dlugosh, L. (2008). Predictors of learning satisfaction in Japanese online distance learners. International Review of Research in Open \& Distance Learning, 9(3), 1-24.

Çelen, F. K., Çelik, A. ve Seferoğlu, S. S. (2011). Yükseköğretimde çevrim-içi öğrenme: Sistemde yaşanan sorunlar ve çözüm önerileri. Journal of European Education, 1(1), 25-34.

Dada, D. (2006). E-readiness for developing countries: moving the focus from the environment to the users. The Electronic Journal on Information Systems in Developing Countries, 27(6), 1-14.

Davis, A. M. (2014). Measuring student satisfaction in online math courses. (Unpublished doctoral dissertation). University of Kentucky, Lexington: KY.

Eom, S. B. (2014). Understanding e-learners' satisfaction with learning management systems. Bulletin of the IEEE Technical Committee on Learning Technology, 16(2/3), 10-13.

Fredericksen, E., Pickett, A., Shea, P., Pelz, W., \& Swan, K. (2000). Student satisfaction and perceived learning with on-line courses: principles and examples from the SUNY learning network. Journal of Asynchronous Learning Networks, 4(2), 7-41. 
Gülbahar, Y. (2012a). Study of developing scales for assessment of the levels of readiness and satisfaction of participants in e-learning environments. Ankara University Journal of Faculty of Educational Sciences, 45(2), 119-137.

Gülbahar, Y. (2012b). e-Öğrenme. Ankara: Pegem.

Hanafizadeh, P., Hanafizadeh, M. R., \& Khodabakhshi, M. (2009). Taxonomy of ereadiness assessment measures. International Journal of Information Management: The Journal for Information Professionals, 29(3), 189-195.

Hukle, D. R. L. (2009). An evaluation of readiness factors for online education (Unpublished doctoral dissertation). Mississippi State University, Mississippi.

Hung, M., Chou, C., Chen, C., \& Own, Z. (2010). Learner readiness for online learning: Scale development and student perceptions. Computers \& Education, 55, 1080-1090.

Ilgaz, H., \& Gülbahar, Y. (2015). A snapshot of online learners: e-readiness, e-satisfaction and expectations. The International Review of Research in Open and Distributed Learning, 16(2), 171-187.

İlhan, M. ve Çetin, B. (2013). Çevrimiçi öğrenmeye yönelik hazır bulunuşluk ölçeği'nin (ÇÖHBÖ) Türkçe formunun geçerlik ve güvenirlik çalışması. Eğitim Teknolojisi Kuram ve Uygulama, 3(2), 72-101.

Jung-Wan, L., \& Mendlinger, S. (2011). Perceived self-efficacy and its effect on online learning acceptance and student satisfaction. Journal of Service Science \& Management, 4(3), 243-252.

Kalelioğlu, F. ve Baturay, M. H. (2014). E-öğrenme için hazır bulunuşluk öz değerlendirme ölçeğinin Türkçeye uyarlanması: Geçerlik ve güvenirlik çalışması. Başkent University Journal of Education, 1(2). 22-30.

Karasar, N. (1991). Bilimsel araştırma yöntemi (4. basım). Ankara: Nobel Yayın Dağıtım. Karuppan, C. M. (2001). Web-based teaching materials: a user's profile. Internet Research: Electronic Networking Applications and Policy, 11(2), 138-148.

Koçlar, S. ve Doğan, T. G. (2015). Türkiye'deki açık ve uzaktan öğrenme programlarının bir analizi: Eğilimler ve öneriler. Ĕgitim ve Öğretim Araşttrmaları Dergisi, 4(4), 23-36.

Korkmaz, Ö., Çakır, R. ve Tan, S. (2015). Öğrencilerin e-öğrenmeye hazır bulunuşluk ve memnuniyet düzeylerinin akademik başarıya etkisi. Ahi Evran Üniversitesi Kırşehir Eğitim Fakültesi Dergisi (KEFAD), 16(3), 219-241.

Lee, H. J., \& Rha, I. (2009). Influence of structure and interaction on student achievement and satisfaction in web-based distance learning. Educational Technology \& Society, 12(4), 372-382.

Machado, C. (2007). Developing an e-readiness model for higher education institutions: Results of a focus group study. British Journal of Educational Technology, 38(1), 7282.

Moore, M. G., \& Kearsley, G. (2012). Distance education: A systems view of online learning. Belmont, CA: Wadsworth, Cengage Learning.

Özkul A. E. (2003). E-öğrenme ve mühendislik eğitimi. Elektrik Mühendisliği, 41(419), 18 27.

Paechter, M., Maier, B., \& Macher, D. (2010). Students' expectations of and experiences in e-learning: Their relation to learning achievements and course satisfaction. Computers \& Education, 54, 222-229. 
Palmer, S. R., \& Holt, D. M. (2009). Examining student satisfaction with wholly online learning. Journal of Computer Assisted Learning, 25, 101-113.

Pena, M., \& Yeung, A. (2010). Satisfaction with online learning: does students' computer competence matter? International Journal of Technology, Knowledge \& Society, 6(5), 97-108.

Senemoğlu, N. (2009). Gelişim, ögrenme ve öğretim: Kuramdan uygulamaya. Ankara: Pegem Akademi.

Shee, D. Y., \& Wang, Y. S. (2008). Multi-criteria evaluation of the web-based e-learning system: A methodology based on learner satisfaction and its applications. Computers and Education, 50, 894-905.

Shraim, K., \& Khlaif, Z. (2010). An e-learning approach to secondary education in Palestine: Opportunities and challenges. Information Technology for Development, 16(3), 159-173.

Simonson, M., Smaldino, S., Albright, M., \& Zvacek, S. (2012). Teaching and learning at a distance: Foundations of distance education (5th ed.). Boston, MA: Pearson.

Stephen, M., Mutula, S. M., \& Brakel, P. (2006). An evaluation of e-readiness assessment tools with respect to information access: Towards an integrated information rich tool. International Journal of Information Management, 26, 212-223.

Sun, P. C., Tsai, R. J., Finger, G., Chen, Y. Y., \& Yeh, D. (2008). What drives a successful e-Learning? An empirical investigation of the critical factors influencing learner satisfaction. Computers \& Education, 50, 1183-1202.

Swan, K., Shea, P., Fredericksen, E. E., Pickett, A. M., \& Pelz, W. E. (2000). Course design factors influencing the success of online learning. Paper presented at WebNet 2000 World Conference on the WWW and Internet, San Antonio, TX.

Tait, A. (2010). Foreword. In M. F. Cleveland-Innes \& D. R. Garrison (Eds.), An introduction to distance education: Understanding teaching and learning in a new era (pp. ix-xi). New York: Routledge.

Trenholm, S. (2013). Adaptation of tertiary mathematics instruction to the virtual medium: approaches to assessment practice. (Unpublished doctoral dissertation). Loughborough University, UK.

Warner, D., Christie, G., \& Choy, S. (1998). Readiness of VET clients for flexible delivery including on-line learning. Brisbane: Australian National Training Authority.

Watkins, R., Leigh, D., \& Triner, D. (2004). Assessing readiness for e-learning. Performance Improvement Quarterly, 17(4), 66-79.

Wu, J. H., Tennyson, R. D., \& Hsia, T. (2010). A study of student satisfaction in a blended e-learning system. Computers \& Education, 55(1), 155-164.

Yurdugül, H., \& Sirakaya, D. A. (2013). The scale of online learning readiness: A study of validity and reliability. Education and Science, 38(169), 391-406. 


\section{Kaynak Gösterme}

Adnan, M. ve Boz-Yaman, B. (2017). Mühendislik öğrencilerinin e-öğrenmeye dair beklenti, hazır bulunuşluk ve memnuniyet düzeyleri. Türk Bilgisayar ve Matematik Eğitimi Dergisi, 8(2), 218-243.

\section{Citation Information}

Adnan, M. \& Boz-Yaman, B. (2017). Profile of engineering undergraduates on readiness and satisfaction for e-learning. Turkish Journal of Computer and Mathematics Education, 8(2), 218-243. 